\title{
VALUE OF A DIPSTICK BASED ON RECOMBINANT RK39 ANTIGEN FOR DIFFERENTIAL DIAGNOSIS OF AMERICAN VISCERAL LEISHMANIASIS FROM OTHER SYMPATRIC ENDEMIC DISEASES IN VENEZUELA
}

\author{
DELGADO O.*, FELICIANGELI M.D.**, CORASPE V.*, SILVA S.*, PEREZ A.* \& ARIAS J.***
}

Summary :

A laboratory trial using recombinant rK39 dipsticks for differential diagnosis of American visceral leishmaniasis (AVL) from other sympatric endemic diseases which share similar clinic features (Chagas disease, malaria, schistosomiasis and toxoplasmosis) was conducted in Venezuela. The $100 \%$ specificity of the test previously obtained in other countries was confirmed. The use of this test at the primary health care level in Venezuela for a rapid diagnosis of active AVL cases, which may avoid deaths, is recommended.

KEY WORDS : American Visceral Leishmaniasis, IK39, dipstick, differentia diagnosis
Résumé : Diagnostic différentiel de la leishmaniose VISCÉRAle al VENEZUELA À L'AIDE DE BANDELETTES IMPRÉGNÉES D'ANTIGÈNE RECOMBINANT RK39

Une étude utilisant des bandelettes imprégnées d'antigène recombinant rK39 a été menée en laboratoire pour le diagnostic différentiel de la leishmaniose viscérale des autres maladies endémiques au Venezuela présentant des similitudes cliniques (maladie de Chagas, paludisme, schistosomiase, toxoplasmose). La spécificité du test (100\%), déjà observée dans d'autres études, a été confirmée. L'utilisation de ce test au niveau des soins de santé primaires est recommandée pour un diagnostic précoce de la leishmaniose viscérale américaine.

MOTS CLÉS : leishmaniose viscérale américaine, bandelettes imprégnées, $K$ K39 diagnostic différentiel.
A merican visceral leishmaniasis (AVL) is a serious parasitic disease distributed in Argentina, Bolivia, Brazil, Colombia, Costa Rica, El Salvador, Guatemala, Honduras, Mexico, Nicaragua and Venezuela (Arias et al., 1996). In Venezuela its magnitude is not well known, mainly because clinic features are shared with other endemic diseases and diagnosis is difficult. It is accepted that some fatal AVL cases might be erroneously attributed to malaria, schistosomiasis, Chagas disease or toxoplasmosis. Finding Leishmania spp. parasites in bone marrow, which is the unequivocal evidence for etiologic diagnosis, is not practiced in Venezuelan rural areas. On the other hand, this method has a low sensitivity because of a low parasitic burden. Serological methods (e.g. IFAT), which are only available in specialized diagnostic centers in Venezuela, show high sensitivity but not always high specificity (Camargo \& Rebonato 1969; Badaró et al., 1983). The use of a dipstick based on the recombinant rK39 antigen of a sequence of 298 aminoacids and an improved serological procedure has showed to

\footnotetext{
* Instituto de Medicina Tropical, UCV, Caracas, Venezuela.

** Universidad de Carabobo, CNRFV/BIOMED, Núcleo Aragua, Maracay, Venezuela

*** Unidad de Enfermedades Transmisibles, OPS/OMS, Washington, USA.

Correspondence: M. Dora Feliciangeli.

Tel.: ++582432425822 - Fax: ++582432425333

e-mail: mdora@telcel.net.ve
}

be practical and reliable for the diagnosis of visceral leishmaniasis in the New World (Badaró et al., 1996) and in the Old World (Sundar et al., 1998). Here we present results of the first application of the rK39 dipstick for differential diagnosis between AVL and other sympatric parasitic diseases in Venezuela.

\section{MATERIALS AND METHODS}

S era of patients kept at the Instituto de Medicina Tropical of the Universidad Central de Venezuela with diagnosis of AVL (41), malaria (20), schistosomiasis (10), Chagas disease (12) and toxoplasmosis (14) were tested using a recombinant rK39 antigen (InBios International, Inc). The diagnosis of AVL was based on the positivity of at least two of the following tests: bone marrow examination, immunofluorescence antibody test (IFAT), counterimmuno-electrophoresis (CIEP) and Western blotting, as previously described (Delgado et al., 1998). Plasmodium vivax and P. falciparum had been detected by microscopical observation. Schistosomiasis had been demonstrated by Schistosoma mansoni eggs in feces and by the circumoval test (Oliver- Gonzalez, 1954). Complement fixation test (Machado Guerreiro's test) and IFAT were used for Chagas Disease diagnosis (Almeida \& Fife, 1976). Toxoplasmosis was determined by ELISA (Voller et al., 1976) and indirect agglutination test (Jacobs \& Lundle, 1957). 
Sera from 10 patients with localized cutaneous leishmaniasis (LCL) and 10 with mucocutaneous leishmaniasis (MCL) were also included in the study to discard cross reaction to species-specific Leishmania spp. antibodies. The rK39 dipstick test was assayed three times for each sample. Simultaneous IFAT using leishmanial antigen was always done, allowing us to determine the comparative specificity and sensitivity of both tests.

The methodology used for the dipstick test followed standard recommendations: one drop of serum was applied to the absorbent pad at the bottom of the strip. After air drying, three drops of test strip buffer (protein A-colloidal gold conjugate) were added. All dipstick results were recorded at five minutes after applying the buffer solution.

\section{RESULTS}

T The appearance of a red upper band (control) indicating the presence of $\operatorname{IgG}$, demonstrated proper test functioning. The appearance of a lower red band revealed the presence of IgG anti-rK39, indicating a positive test for AVL. When comparing results of proved AVL positive sera against sera positive to other diseases, a $100 \%$ of specificity was demonstrated. Conversely, IFAT showed cross-reaction for Chagas disease, LCL and MCL (titer $=1: 256$ ). Dipstick sensitivity in sera positive for AVL was $87.8 \%$ (36/41) while IFAT sensitivity was $100 \%$. When results were analyzed as function of time of sera storage it was detected that sera that were negative to dipstick test (but positive to IFAT) had been kept in the laboratory at $-70^{\circ} \mathrm{C}$ for more than 10 years (1974-1983). In fact, no significant difference was detected when comparing results obtained with sera stored during 1974-1978 (24-20 years before), 1979-1983 (19-15 years) and 1984-1988 (10-15 years of storage) (Fisher exact test), but significant difference was obtained comparing results of each of these groups of samples with those from sera collected between 1989-1993 and 1994-1998 (Fisher exact test: $\mathrm{p}>0.01$ ).

\section{DISCUSSION}

\section{A}

60-second dipstick for a rapid diagnosis of visceral leishmaniasis has being recently used (Sundar et al., 1998; Jelinek et al., 1999). Results on the sensitivity of tests using this antigen have led, to a certain extent, to different interpretations. Some authors refer a very high sensitivity in active AVL, being positive in acute infections and subclinical progressing to VL infections, while asymptomatic and subclinical self-healing patients would be negative (Badaró et al., 1996). Sundar et al. (1998) refer $100 \%$ sensitivity in all patients with positive spleen aspirate, that would indicate active infection, while they obtained four positive results in patients with negative spleen aspirate direct smears that were also interpreted as subclinical no-self healing infection. On the other hand, false negatives (28.6\%) were detected among 14 samples by Jelinek et al. (1999). These authors state that the reason for the false negative reactions remains unclear, so they do not consider that the rK39 dipstick as a reliable and conclusive test for VL diagnosis. We observed loss of reactivity in sera kept more than nine year, which may be due to protein degradation in longterm stored samples (Margulies, 1996).

The presence of specific antibodies is detected by the recombinant product $\mathrm{rK} 39$ with a repetitive epitope closely conserved between Leishmania chagasi and L. donovani, which is part of a large kinesin related protein expressed predominantly by amastigotes (Reed, 1990; Burns et al., 1993). A $100 \%$ specificity of this protein had been previously reported in Brazil using sera from patients with tropical diseases other than AVL (Badaró et al., 1996). A good specificity has been also reported in the Old World (Singh et al., 1995; Sundar et al., 1998; Jelinek et al., 1999). In Venezuela AVL, Chagas Disease, malaria, schistosomiasis and toxoplasmosis overlap in some areas. These diseases share clinical symptoms and signs, therefore the clinical-epidemiological diagnosis is of scarce value, even in endemic areas. The major need for a rural medical doctor is to handle a reliable test for an early diagnosis of AVL in order to apply the opportune specific treatment. The high specificity of the rK39 antigen to differentiate from sympatric parasitic diseases other than AVL in Venezuela, allows us to recommend the routine use of this simple and low cost dipstick test for a rapid diagnosis of suspected AVL cases in rural area primary care centers, since it may indeed avoid deaths. Suspected AVL cases which would result negative, should be referred to the closest hospital to be confirmed by other serological or parasitological techniques.

\section{ACKNOWLEDGEMENTS}

This work received financial support from $\mathrm{CDCH}-$ UCV, Project 09-10-3682-99 and PCEE-VEN96002-006 (Commitment Venezuelan GovernmentWorld Bank).

\section{REFERENCES}

Almeida J.O. \& Fife E.H. Jr. Método de fijación de complemento estandarizado cuantitativamente para la evaluación crítica de antígenos preparados con Trypanosoma cruzi. OPS, Publicaciones Científicas, Washington, 1976, 319. 
Arias J.R., Monteiro P.S. \& Zicker F. The reemergence of visceral leishmaniasis in Brazil. Emerging Infectious Diseases. 1996, 2, 145-146.

Badaro R., Reed S.G. \& Carvalho E.M. Immunofluorescent antibody test in American visceral leishmaniasis: sensitivity and specificity of different morphological forms of two Leishmania species. American Journal of Tropical Medicine and Hygiene, 1983, 32, 480-484.

Badaró R., Benson D., Eulalio M.C., Freire M., Cunha S., Netto E.M., Pedral-Sampaio D., Madureira C., Burns J.M., Houghton R.L., David J.R. \& ReED S.G. rK39: a cloned antigen of Leishmania chagasi that predicts active visceral leishmaniasis. The Journal of Infectious Diseases, 1996, $173,758-761$

Burns J.M. Jr., Shreffler W.G., Benson D.R., Ghalib H.W., BADARó R. \& REED S.G. Molecular characterization of a kinesin-related antigen of Leishmania chagasi that detects specific antibody in African and American visceral leishmaniasis. Proceedings of Natural Academy of Sciences, USA, 1993, 90, 775-779.

Camargo M.E. \& Rebonato C. Cross-reactivity in the immunofluorescence test for Trypanososma and Leishmania antibodies. A simple inhibition procedure to ensure specific results. American Journal of Tropical Medicine and Hygiene, 1969, 18, 500

Delgado O., Feliciangeli M.D., Gomez B., Alvarado J., GarCía L. \& Bello C. The re-emergence of American visceral leishmaniasis in an old focus in Venezuela: present situation of human and canine infections. Parasite, 1998, 5, 317323.

Jacobs L. \& Lunde M.N. A haemagglutination test for toxoplasmosis. Journal of Parasitology, 1957, 43, 308-314.

Jelinek T., Eichenlaub S. \& Löscher T. Sensitivity and specificity of a rapid inmunochromatographic test for diagnosis of visceral leishmaniasis. European Journal of Clinics and Microbiology of Infectious Diseases, 1999, 18, 669-670.

MaRgulies D.H. Current protocols in immunology: antibody detection and preparation. Vol. 1, Chapter 2. Unit 2, 4, 6. National Institute of Allergy and Infectious Diseases. John Wiley \& Son (eds). Philadelphia, USA, 1996.

Oliver-Gonzalez J. Anti-eggs precipitins in sera of human infected with Schistosoma mansoni. Journal of Infectious Diseases, 1954, 95, 86-91.

Pappas M.G., Mc Greevy P.B., Hajkowski R., Hebdricks L.D., Oster C.N. \& Hockmeyer W.T. Evaluation of promastigote and amastigote antigens in the indirect fluorescent antibody test for American cutaneous leishmaniasis. American Journal of Tropical Medicine and Hygiene, 1983, 32, 1260-1267.

Reed S.G., Shreffler W.G., Burns J.M. Jr, Scott J.M., Orge M.G., Ghalib H.W., Siddig M. \& Badaró R. An improved serodiagnostic procedure for visceral leishmaniasis. American Journal of Tropical Medicine and Hygiene, 1990, 43, 632-639.

Singh S., Gilman-Sachs A.G., Chang K.P. \& Reed S.G. Diagnostic and prognostic value of $\mathrm{K} 39$ recombinant antigen in Indian leishmaniasis. Journal of Parasitology, 1995, 81, 1000-1003.
Sundar S., Reed S.G., Singh V.P., Kumar C.K. \& Murray H.W. Rapid accurate field diagnosis of Indian visceral leishmaniasis. Lancet, 1998, 351, 563-565.

Voller A., Bidwell D.E., Bartlett A., Fleck D.S., Perkins M. \& Oladehin B. A microplate enzyme-immuno-assay for Toxoplasma antibody. Journal of Clinical Patbology, 1976, 29, 150-153.

Reçu le 10 novembre 2000 Accepté le 10 octobre 2001 